\title{
Relationship and Impact of Service Quality, Destination Image, on Customer Satisfaction and Revisit Intention to Syariah Destination in Madura, Indonesia
}

\author{
Pribanus Wantara and S. Anugrahini Irawati
}

\section{ABSTRACT}

Madura is one of the sharia tourist attractions in Indonesia, so many local and foreign tourists come to Madura Island to carry out sharia tours by visiting Islamic places such as mosques, tombs of the great Madurese clerics, and halal culinary places. In the conditions of the COVID-19 pandemic which has been going on for one year, government policy has closed these sharia tourist spots. However, since the number of Covid 19 cases, especially on Madura Island, has decreased significantly, the government has allowed opening these sharia tourist spots with the provisions of health protocols. The purpose of this study is to examine the relationship between service quality, destination image, and customer satisfaction on the revisit intention of tourists to tour destination religious in Madura. Data were collected from a questionnaire survey and empirical studies were conducted using structural equation modeling (SEM) to test the hypotheses, as well as the structural relationships between these factors. The results of empirical studies confirm that service quality and destination image make a positive contribution to tourist satisfaction, then that the service quality contribute to the revisit intention, but the destination image does not contribute to the revisit intention, and tourist satisfaction contributes positively to the revisit intention. Furthermore, this study also contributes to the managers of sharia tourist destinations in Madura to analyze the relationship between service quality attributes and destination image to revisit intention by improving the services provided, thereby contributing to increasing the number of tourists, and implementing sustainable service quality policies.

Keywords: customer satisfaction, destination image, service quality, revisit intention, structural equation model, syariah destination.

\section{INTRODUCTION}

The development of tourism in Madura also contributes to the development of other sectors of the economy. Because tourism is a multi-sector economy, which means that it does not only provide one kind of product or service. In its development, tourism which is increasingly in demand also spurs the growth of other sectors, which are expected to accelerate development in the Madura region as much awaited by the public and the government. The acceleration of development is not only in the field of tourism, of course, in terms of facilities and infrastructure that meet the standard needs of the community so that it becomes feasible to be conveyed to local people and tourists who will come. Madura Island itself with high tourism potential (especially natural tourism and halal tourism) as well as the support of religious culture from the local Madurese community makes Madura Island a visiting place for religious tourists.

As it is known that Madura Island has a Muslim population with Islamic boarding schools, large mosques that are scattered to remote areas of Madura Island, and many great figures or scholars who were born from Madura Island. This makes Madura Island attractive for
Submitted : December 03, 2021

Published : December 25, 2021

ISSN: $2507-1076$

DOI: $10.24018 /$ ejbmr.2021.6.6.1192

Wantara, Pribanus *

Management Department, Economic and Business Faculty, University of Trunojoyo Madura, Indonesia. (e-mail:

pribanus.wantara@trunojoyo.ac.id) Irawati, S. Anugrahini

Management Department, Economic and Business Faculty, University of Trunojoyo Madura, Indonesia.

(e-mail:

anugrahini.irawati@trunojoyo.ac.id)

*Corresponding Author local and foreign tourists. In the current state of the Covid 19 pandemic, due to health protocol regulations, many tourist destinations must be closed, so that tourists cannot come to visit tourist destinations on Madura Island. However, after the number of COVID-19 cases on Madura Island was controlled, the government began to open this sharia tourist destination even with various restrictions. Tourist destinations frequented by religious tourists are the Tomb of Syaikhona Kholil, the Mubarok Mosque, and the Aeng Mata Ebuh Tomb in the city of Bangkalan, the Great Mosque of Sumenep, Batu Ampar, and the Tomb of Asta Tinggi in Sumenep City.

Various approaches have been used by tourism agencies and planners to improve the quality of tourism destination services according to visitor needs, such as increasing investment in service quality, assessing tourist satisfaction, and finding out gaps that must be overcome. Even so, the expectations of tourists in providing services are still not appropriate (Pan et al., 2010). Tourist destination managers in Madura also do not have accurate measurement tools to find out factors for shortages in their destination image, which are an important prerequisite for improving services, increasing visitor satisfaction, and implementing sustainable service policies. There are many studies on 
service quality (Wantara, 2015; Eboli \& Mazzulla, 2012; Hassan et al., 2013). The most relevant literature consists of case studies and visitor questionnaire surveys, which identify important factors and provide useful advice from different perspectives (Eboli \& Mazzulla, 2011; Nathanail, 2008).

Structural equation model (SEM) is used in this article to examine the relationship between service quality and destination image that leads to tourist satisfaction and the revisit intention of tourists to Madura. A good understanding of the relationship between these variables will produce information in making decisions about future tourism services at religious tourism destinations and implementing sustainable service policies.

\section{LITERATURE REVIEW AND HYPOTHESES}

\section{A. Service Quality}

Service quality is the impression that consumers have of the relative inferiority or superiority of the organization and its services (Bitner and Hubbert, 1994). This concept is based on that service quality is an accumulation of consumer perception activities on organizational performance (Rossiter, 2002). This assumption assumes that if organizations maintain quality levels, they will provide satisfaction to consumers (Wu et al., 2014). In the tourism industry, service quality measurement generally uses SERVQUAL developed by Parasuraman et al. (1988) and SERVPERF (Cronin and Taylor, 1992).

\section{B. Destination Image}

Lawson and Baud Bovy (1977) explain that the image of a destination is the objective knowledge, prejudice, imagination, and emotional thoughts of individuals and groups towards a particular location. An image is something abstract (intangible) that cannot be tasted, seen, heard, smelled, or felt, so the service provider company must really be able to convince potential tourists and provide tangible evidence to tourists when they are in tourist destinations. Image can also give the impression that a destination will provide an attraction that is different from other destinations, which actually offer attractions that are not much different, thereby increasing the desire to visit that destination (Pitana and Gayatri, 2005).

\section{Tourist Satisfaction}

Customer satisfaction is the degree to which customers feel happy about the vendor's ability to meet the needs and expectations of consumers. The most prominent definition of satisfaction put forward by Oliver (1997) says that customer satisfaction is the result of evaluating the difference between customer expectations and the quality received. According to Abubakar, and F. Mavondo (2014), satisfaction is an assessment of the tourist experience, which has been widely studied in the context of tourism. Furthermore, Brady and Robertson argue that satisfied tourists are an important source of information to satisfy potential tourists and play an important role in tourism marketing. The concept of satisfaction has attracted considerable attention from scholars because of its positive impact on profitability, loyalty, and future repeat business (Zeithaml et al., 2009).

\section{Revisit Intention}

Baker and Crompton (2000) stated that the intention to visit again is the intention and desire to visit more often. Therefore, it is very important for service providers to provide satisfaction for visitors so that they want to visit again (Shonk \& Chelladurai, 2008). One of the important factors influencing revisit intention is satisfaction (Bigné et al., 2001).

\section{E. Relationship between Service Quality and Satisfaction}

According to Tjiptono (2012), service quality is an effort to fulfill consumer needs and desires as well as the accuracy of delivery in balancing consumer expectations, meanwhile Parasuraman et al. (1988) defined service quality as "a function of the difference between the service expected and the customer's perception of the service actually provided". Several researchers have shown that service quality leads to customer satisfaction (Wantara, 2015). The relationship between service quality and satisfaction has been confirmed by various studies in several different contexts. Tourism background research shows a correlation between service quality and satisfaction (Wantara, 2015; Chen \& Chen, 2010; González et al., 2007). Zeithaml and Bitner (2003) indicate that consumer satisfaction is influenced by consumer quality perceptions. Service quality is an antecedent of customer satisfaction (Lee et al., 2000). The relationship between service quality and loyalty is mediated by satisfaction (Caruana, 2002; Fullerton and Taylor, 2002).

\section{F. Relationship between Destination Image and Satisfaction}

Image is a function of accumulated consumption over time (Andreassen and Lindestad, 1998) or the cumulative effect of consumer satisfaction and dissatisfaction (Bolton \& Drew, 1991; Fornell, 1992). Ball et al. (2004) noted that the level of corporate image affects customer satisfaction with service providers.

\section{G. Relationship between Service Quality and Revisit Intentions}

According to Shen et al. (2016) that service quality is an important factor in increasing the intention of revisit tourists. This statement is supported by the results of research conducted by Canming \& Jianjun (2011) which states that the intention of tourists to visit again is influenced by service quality.

\section{H. Relationship between Destination Image and Revisit Intentions}

To maintain the intention of tourists to come back, companies should not ignore aspects of corporate image (Yang, 2014; Yang \& Wu, 2013). Destination image has a positive relationship with revisit intentions seen in several studies in the tourism sector (Raheem et al., 2014;). Thus, the image of the destination can be a tourist intention to make future visits or to recommend it to others. 


\section{Relationship of Satisfaction and Revisit Intentions}

The results of research conducted by Kim, Kim, \& Goh. (2011) obtained that results that customer satisfaction is positively and significantly related toward customer repurchase intentions. Satisfaction is a determinant component of return tourist visits (Kim et al., 2011; Cronin and Taylor, 1992). Visitor satisfaction is an important aspect of the intention to visit again.

Based on the above thinking, this article has identified the relationship between service and destination image, tourist satisfaction and return visit intention, so that the proposed hypothesis:

Hypothesis $1(\mathrm{H} 1)$ : service quality has a positive effect on customer satisfaction.

Hypothesis 2 (H2): destination image has a positive effect on customer satisfaction.

Hypothesis $3(\mathrm{H} 3)$ : service quality has a positive effect on revisit intentions.

Hypothesis $4(\mathrm{H} 4)$ : the image of the destination has a positive effect on revisit intentions.

Hypothesis 5 (H5): customer satisfaction has a positive effect on revisit intentions.

\section{RESEARCH METHODOLOGY}

The survey instrument in this study was designed to investigate tourist perceptions of the various dimensions of tourism services as mentioned in Table I. The items in this questionnaire follow the five dimensions compiled by Parasuraman et al. (1985), however, this item was changed to be adjusted for the category of sharia tourism services (see Table I). In general, the questionnaire covers two main areas. The first part contains questions about the demographic characteristics of the respondents. These characteristics include gender, age, education level, marital status, nationality, and occupation. In addition, respondents were asked to state: the number of their previous visits to this area; their willingness to revisit sharia tourist destinations on Madura Island; their willingness to recommend Madura as a sharia tourism destination to others. The second part includes 22 items, using a 5-point scale anchored from $1=$ Strongly Disagree to $5=$ Strongly Agree. The contents of these items are detailed in Table I.

\section{A. The SEM Model}

SEM is a multivariable statistical technique that allows researchers to solve complex structural problems expressed in a series of equations. So that it can evaluate the causal relationship between latent variables and test hypotheses. Fornel and Larker (1981) stated that latent variables include exogenous variables and endogenous variables. The basic equation of the structural model can be defined by the following equation (Bollen, 1989). The maximum likelihood method (ML) was used to estimate the model parameters. The ML method is estimated by minimizing the difference between the predicted variance-covariance matrix and the observed variance matrix and taking into account the model constraints.

\section{B. Data Collection}

In order to obtain accurate and unambiguous responses from the respondents, the questionnaire was first tested on a pilot group consisting of 3 people based on easy sampling. The questionnaire survey was conducted in Madura, Indonesia. The pilot group consisted of academics and related experts. The pilot group not only gave responses to the statements on the questionnaire, but the pilot group also gave some suggestions to get a better understanding of the question. Their suggestions were included to improve the questionnaire. The final questionnaire maps a scale from 1 to 5 points to represent differences in tourist attitudes $(1=$ strongly disagree; $5=$ strongly agree). A total of 250 questionnaires were conducted and 187 effective responses were received. The survey was conducted in religious tourism destinations such as mosques and other sharia destinations in the morning and evening and was conducted on different days of the week, namely in July and August 2021. Questionnaires were given randomly and face to face to tourists.

TABLEI: TOURIST SERVICE DIMENSIONS

\begin{tabular}{|c|c|}
\hline Dimension & Item Label and Wording \\
\hline \multirow[t]{4}{*}{ Assurance } & 1 Provided trained and customer-oriented personnel \\
\hline & 2 The level of service quality strengthens my confidence in the services provided \\
\hline & $\begin{array}{l}3 \text { Experienced and competent tour escort personnel are provided to make it easier for me to travel sharia } \\
\text { on the island of Madura. }\end{array}$ \\
\hline & 4 The staff communicated with me smoothly and was easy to understand. \\
\hline \multirow[t]{6}{*}{ Responsiveness } & 5 The staff sincerely helped solve my problem. \\
\hline & 6 The staff provides me with adequate and clear information \\
\hline & 7 The staff fulfills my request promptly and on time \\
\hline & 8 The staff provides complete information about the entertainment offered \\
\hline & 9 The staff shows genuine willingness and interest in helping and assisting me \\
\hline & 10 The staff gave me advice on how to best make the most of my free time \\
\hline \multirow[t]{4}{*}{ Reliability } & 11 Services delivered were correct from the first time \\
\hline & 12 Services were delivered as promised to tourists \\
\hline & 13 Scheduled tours were met on a timely manner \\
\hline & 14 No troubles occurred with the service provided during my stay in the Madura Island \\
\hline \multirow[t]{5}{*}{ Tangibles Facilities } & 15 There are modern worship facilities and according to sharia standards \\
\hline & 16 Infrastructure is well designed and compliant with sharia standards \\
\hline & 17 Food served halal according to sharia standards \\
\hline & 18 Accommodations and facilities are attractive and designed according to sharia standards \\
\hline & 19 The appearance of the tour guide is neat and clean according to sharia standards \\
\hline \multirow[t]{3}{*}{ Empathy } & 20 Pleasant and friendly personnel provided services offered. \\
\hline & 21 My exceptions and special needs were met as expected \\
\hline & 22 Personal safety was considered as a major aspect in every service provided \\
\hline
\end{tabular}




\section{RESUlTS AND Discussions}

\section{A. Descriptive Analysis}

Data collection was carried out for two months, namely July and August 2021. The research population was sharia tourists in Madura. The basic characteristics of tourists are shown in Table II, the sample consists of more women (57.3\%). Most of the respondents were over 60 years old (29\%), followed by $25.9 \%$ between 46 and 60 years old, $23.0 \%$ between 31 and 45 years old, and $21.8 \%$ between 18 and 30 years old. Most tourists $(35.5 \%)$ stated that they visited a religious tourism destination in Madura every year, and $25.9 \%$ had visited a religious destination only once. Most tourists visit religious tourism destinations as a form of sunnah worship and the rest want to know about religious tourism destinations on Madura Island.

\begin{tabular}{cccc}
\multicolumn{3}{c}{ TABLE II: DEMOGRAPHIC CHARACTERISTIC ON RESPONDENT } \\
\hline Demographic information & $\mathrm{N}$ & $\%$ \\
\hline Gender & Male & 83 & 42.7 \\
& Female & 104 & 57.3 \\
Age (years) & $18-30$ & 41 & 21.8 \\
& $31-45$ & 43 & 23.0 \\
& $46-60$ & 48 & 25.9 \\
Level of education & $60+$ & 55 & 29.3 \\
& Undergraduate & 3 & 14.5 \\
& Graduate & 118 & 62.7 \\
Aim of visit & Postgraduate & 38 & 22.7 \\
& Worship & 85 & 45.2 \\
& Traveling & 36 & 19.5 \\
& Other & 66 & 35.5 \\
\hline Source: Developed by Authors. & &
\end{tabular}

Source: Developed by Authors.

\section{B. Confirmatory Factor Analysis (CFA) For Service Quality Model}

Structural equation modeling (SEM) assumptions were confirmed. At the same time through Confirmatory Factor Analysis (CFA), analysis of the measurement model was carried out to validate the construct to confirm the nature of the measurement. In addition, in addition to the Chisquare value, the researcher uses the recommended goodness of fit index to examine the goodness of fit of the measurement models, such as CFI, GFI, AGFI, and RMSEA. The measurement model consisting of various dimensions of service quality illustrates that the data fits the model very well $(\mathrm{Ch}$-square $=234.142 ; \mathrm{p}$ (probability) $=0.079 ; \mathrm{CMIN} / \mathrm{DF}=1.189 ; \mathrm{RMSEA}=0.038 ; \mathrm{GFI}=$ 0.903).

In addition, the researcher also tested the reliability and validity of the service quality dimensions by following Netemeyer et al. (2003). Table III shows that the composite reliability (CR) value for the model construct has been found to be more than the recommended threshold value of 0.80 . In all cases, the mean value of extracted variance (AVE) was found to be more than the recommended threshold value of 0.50 . The findings of this study support the convergent reliability and the measured construct validity. By examining the squares of all correlation pairs with the mean value of the extracted variance, the discriminant validity of the constructs is checked. In all cases, the results support that the extracted mean variance value is more than the square of the correlation, thus supporting discriminant validity.
TABLE III: FACTOR LOADING MATRICES AND RELIABILITY

\begin{tabular}{|c|c|c|c|c|}
\hline Factor Name & Indicators & Loadings & AVE & CR \\
\hline \multirow{4}{*}{ Assurance } & Ass1 & 0,861 & \multirow{4}{*}{0,752} & \multirow{4}{*}{0,924} \\
\hline & Ass2 & 0,871 & & \\
\hline & Ass 3 & 0,843 & & \\
\hline & Ass4 & 0,894 & & \\
\hline \multirow{6}{*}{ Responsiveness } & Res1 & 0,757 & \multirow{6}{*}{0.787} & \multirow{6}{*}{0,898} \\
\hline & Res2 & 0,722 & & \\
\hline & Res3 & 0,803 & & \\
\hline & Res4 & 0,759 & & \\
\hline & Res5 & 0,723 & & \\
\hline & Res6 & 0,731 & & \\
\hline \multirow{5}{*}{ Reliability } & Rel1 & 0,762 & \multirow{5}{*}{0.732} & \multirow{5}{*}{0.864} \\
\hline & Rel2 & 0,754 & & \\
\hline & Rel3 & 0,710 & & \\
\hline & Rel4 & 0,709 & & \\
\hline & Rel5 & 0,761 & & \\
\hline \multirow{5}{*}{$\begin{array}{l}\text { Tangibles } \\
\text { Facilities }\end{array}$} & Tang1 & 0,736 & \multirow{5}{*}{0.732} & \multirow{5}{*}{0.887} \\
\hline & Tang2 & 0,782 & & \\
\hline & Tang3 & 0,793 & & \\
\hline & Tang4 & 0,762 & & \\
\hline & Tang5 & 0,753 & & \\
\hline \multirow{3}{*}{ Empathy } & Emp1 & 0,799 & \multirow{3}{*}{0.608} & \multirow{3}{*}{0.823} \\
\hline & Emp2 & 0,730 & & \\
\hline & Emp3 & 0,808 & & \\
\hline
\end{tabular}

Source: Developed by Authors.

TABLE IV: GOODNESS OF FIT INDICES

\begin{tabular}{lcccccc}
\hline Indices & $\begin{array}{c}\text { Ch- } \\
\text { square }\end{array}$ & $P$ & CMIN/DF & RMSEA & CFI & GFI \\
\hline Values & 234.142 & 0.079 & 1.189 & 0.038 & 0.973 & 0.903 \\
\hline \multicolumn{7}{l}{ Source: Developed by Authors. }
\end{tabular}

\section{Test the validity and Reliability of Measures}

Explorative factor analysis was conducted to analyze the correlation of indicators and determine the scale on the service quality variable. The value of Cronbach's alpha is $0.716(>0.6)$ which indicates the validity of the measurement. Bartlett's Test of Sphericity was 2380.84 and the associated significance level was 0.000 , indicating that there was a correlation between variables, and factor analysis was effective. Furthermore, the Kaiser-MayerOlkin value was obtained at $0.826(>0.7)$ which indicated that the data in this study were suitable for further factor analysis. After exploratory factor analysis was carried out, confirmatory factor analysis was carried out to measure convergent validity, with a mean of extract variance $(\mathrm{AVE})>0.5$ on all occasions. And the correlation between constructs ranged from 0.021 to 0.685 , so there was no correlation between pairs of sizes that exceeded the criteria (above 0.9). Table III shows the estimation results for confirmatory analysis.

TABLE V: THE VALIDITY AND RELIABILITY OF THE MEASURES

\begin{tabular}{|c|c|c|c|c|c|c|}
\hline Variables & Items & Estimate & $\mathrm{SE}$ & $\mathrm{CR}$ & $P$ & AVE \\
\hline \multirow{5}{*}{$\begin{array}{l}\text { Service } \\
\text { quality } \\
\text { (SQ) }\end{array}$} & SQ1 & 0.784 & 0.123 & 6.400 & $* * *$ & \multirow{5}{*}{0.890} \\
\hline & SQ2 & 0.784 & 0.164 & 4.789 & $* * *$ & \\
\hline & SQ3 $^{\mathrm{a}}$ & 1 & & & & \\
\hline & SQ4 & 1.083 & 0.193 & 5.621 & $* * *$ & \\
\hline & SQ5 & 0.655 & 0.149 & 4.390 & $* * *$ & \\
\hline \multirow{4}{*}{$\begin{array}{l}\text { Destination } \\
\text { Image } \\
\text { (DI) }\end{array}$} & DI1 & 1.301 & 0.316 & 4.118 & $* * *$ & \multirow{4}{*}{1.259} \\
\hline & DI2 & 1.521 & 0.313 & 4.866 & $* * *$ & \\
\hline & $\mathrm{DI}^{\mathrm{a}}$ & 1 & & & & \\
\hline & DI4 & -0.174 & 0.131 & -1.326 & 0.185 & \\
\hline \multirow{4}{*}{$\begin{array}{l}\text { Customer } \\
\text { satisfaction } \\
\text { (CS) }\end{array}$} & $\mathrm{CS} 1^{\mathrm{a}}$ & 1 & & & & \multirow{4}{*}{0.934} \\
\hline & CS2 & 0.900 & 0.144 & 6.229 & $* * *$ & \\
\hline & CS3 & 1.093 & 0.173 & 6.304 & $* * *$ & \\
\hline & CS4 & 0.560 & 0.129 & 4.338 & $* * *$ & \\
\hline \multirow{4}{*}{$\begin{array}{c}\text { Revisit } \\
\text { intention } \\
\text { (RI) }\end{array}$} & $\mathrm{RI}^{\mathrm{a}}$ & 1 & & & & \multirow{4}{*}{0.823} \\
\hline & RI2 & 0.946 & 0.097 & 9.762 & $* * *$ & \\
\hline & RI3 & 1.085 & 0.099 & 10.977 & $* * *$ & \\
\hline & RI4 & 0.470 & 0.107 & 4.378 & $* * *$ & \\
\hline
\end{tabular}

Source: Developed by Authors. 


\section{Structural Model}

Path relationships in this research model were analyzed using SEM. Based on the analysis using Amos 22, the fit index of the overall research model can be accepted, such as: root mean square error approximation (RMSEA)= $0.032(<0.08)$; Goodness-of-fit index $(\mathrm{GFI})=0.923$ (> $0.9)$; adjusted goodness-of-fit index (AGFI) $=0.896$ (> $0.9)$; and comparative fit index $(\mathrm{CFI})=0.970(>0.9)$.

TABLE VI: THE RESULTS OF THE MODEL's GOODNESS-OF-FIT TEST

\begin{tabular}{crccccc}
\hline Indices & $\begin{array}{c}\text { Ch- } \\
\text { square }\end{array}$ & $P$ & CMIN/DF & RMSEA & CFI & GFI \\
\hline Values & 134.342 & 0.083 & 1.189 & 0.032 & 0.970 & 0.923
\end{tabular}

Note. RMSEA $=$ root mean squared error approximation; CFI = comparative fit index; DF = degree of freedom; GFI = goodness-of-fit index; $\mathrm{CMIN}=$ likelihood-ratio chi-square.

Source: Developed by Authors.

The results of SEM calculations that show the relationship of each variable are described in Table VII. The results of this calculation indicate that quality has a significant effect on customer satisfaction $(\mathrm{H} 1=0.411)$ and on revisit intention $(\mathrm{H} 3=0.408)$, while destination image effect on customers satisfaction $(\mathrm{H} 2=0.611)$ and destination image did not affect revisit intention $(\mathrm{H} 4=$ 0.107). Next, customer satisfaction affects revisit intention $(\mathrm{H} 5=0.464)$, and the results support H5. The structural model with standard weights is shown in Fig. 1.
Based on Table VII it can be seen that the quality of service and the image of the destination contribute to tourist satisfaction, this illustrates that the quality of services provided by managers of religious tourism destinations is considered good so that tourists are satisfied with the services, while the image of the destination illustrates that sharia tourist destinations on the island Madura has good tourism potential, the people on the island of Madura still maintain the concept of sharia, which is illustrated by the spread of mosques and Islamic boarding schools on the island of Madura and it is not allowed to open places that are not in accordance with sharia guidelines. Furthermore, service quality has a significant effect on the intention to visit again, while destination image does not have a significant effect on the intention to visit again, this illustrates that the quality of service provided by the manager of tourist destinations is considered good so that tourists are interested in making a return visit at another time, but the destination image offered to tourists in this study is not a factor affecting the intention to visit again. In addition, tourist satisfaction contributes significantly to the intention to return to visit, this means that tourists who are satisfied when visiting religious tourism destinations on Madura Island make tourists intend to visit again at a later date.

TABLE VII: THE RESULTS OF THE MODEL'S HYPOTHESES TESTING

\begin{tabular}{cccccccccccc}
\hline Hypotheses & $\begin{array}{c}\text { Influence } \\
\text { relation }\end{array}$ & $\begin{array}{c}\text { Independent } \\
\text { variable }\end{array}$ & Path & $\begin{array}{c}\text { Dependent } \\
\text { variable }\end{array}$ & Estimate & SE & C.R & $P$ & Result \\
\hline H1 & Direct & SQ & $\rightarrow$ & CS & 0.411 & 0.162 & 2.544 & 0.011 & Support \\
H2 & Direct & DI & $\rightarrow$ & CS & 0.611 & 0.233 & 2.625 & 0.009 & Support \\
H3 & Direct & SQ & $\rightarrow$ & RI & 0.408 & 0.176 & 2.321 & 0.020 & Support \\
H4 & Direct & DI & $\rightarrow$ & RI & 0.107 & 0.229 & 0.469 & 0.639 & Not \\
H5 & Direct & CS & $\rightarrow$ & RI & 0.464 & 0.170 & 2.733 & 0.006 & Support \\
\hline
\end{tabular}

Note. $\mathrm{SQ}=$ Service quality; $\mathrm{CS}=$ customer satisfaction; $\mathrm{DI}=$ destination image, $\mathrm{RI}=$ Revisit intention.

Source: Developed by Authors.

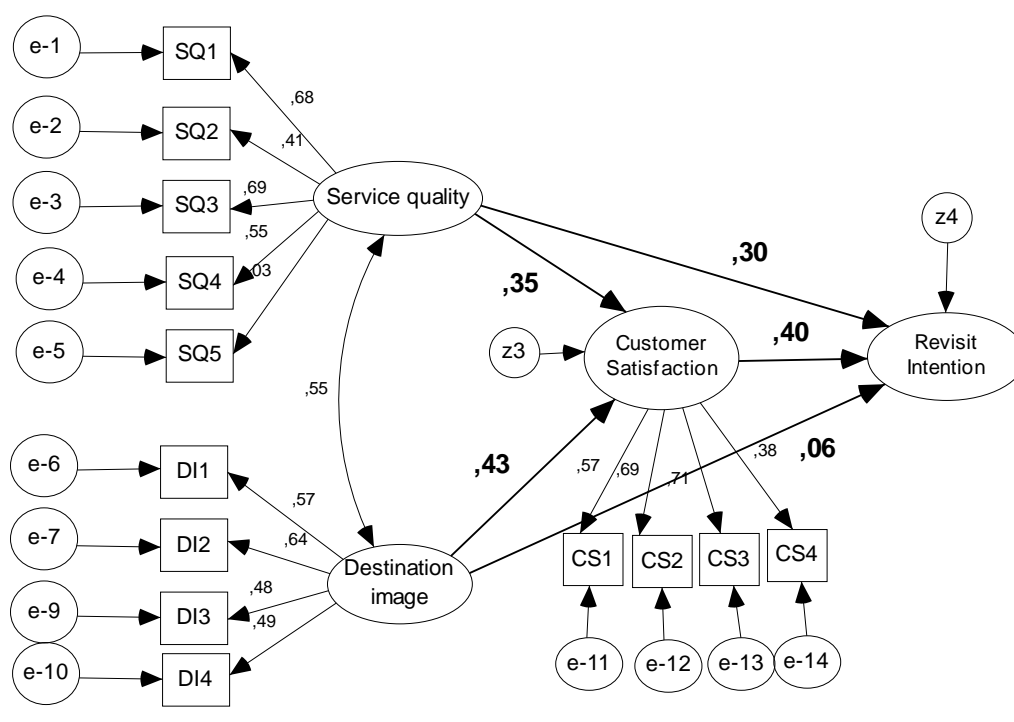

Fig. 1. The hypothesized model with path coefficients.

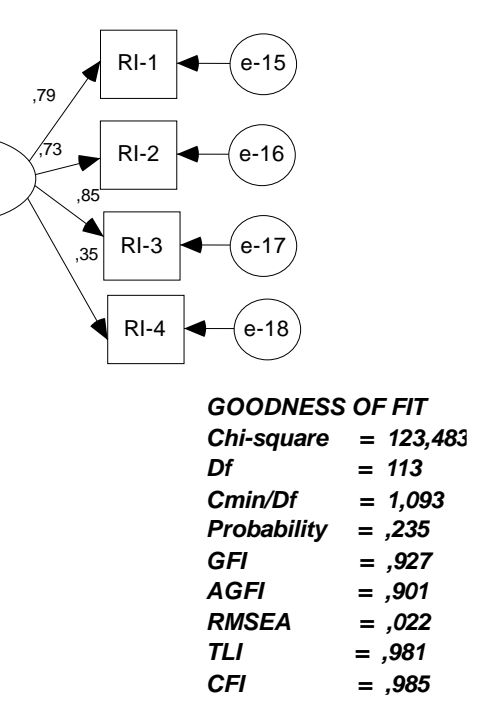




\section{CONCLUSION AND MANAGERIAL IMPLICATIONS}

Indonesia is now working to restore economic development that was slumped due to the outbreak of the COVID-19 pandemic, especially for the economy of people around tourist destinations, transportation, travel businesses, and so on.

The purpose of this study has three aspects: (a) understanding tourists' perceptions and expectations of service quality and destination image, (b) developing and testing measuring service quality dimensions, and (c) studying the relationship between service quality, destination image, customer satisfaction, and the intention to visit again. From these results, it can be seen that service quality and destination image play a very important role in tourist satisfaction and have a positive impact on the intention of visiting tourists again. By analyzing tourist perceptions, tourist destination managers can understand the needs of tourists and try to improve the quality of services and in particular, the destination image must match the demands of tourists. In addition, tourist satisfaction can help managers understand the effectiveness and acceptance of tourists and play a positive role in attracting tourists to visit again. This deepens our understanding of the factors that influence tourists in choosing religious tourism destinations.

The conclusion drawn from this study is that this research has important implications for future researchers and tourism destination managers. The model produced in this study can be extended to other tourism objects, to fully assess the factors that cause the intention to return to visit. This study improves the link between service quality, destination image, customer satisfaction, and intention to return to visit. These findings have implications for policymakers who are responsible for implementing and promoting religious tourism destinations in Madura, as well as for researchers who are interested in developing theories that explain the relationship between service quality, destination image, customer satisfaction, and intention to return to visit. Therefore, policymakers should pay more attention to the quality of services and destination image. According to this study, service planning and reliability are the most important factors. We recommend that a well-designed tourist destination can increase visitor enjoyment, increase accessibility to the destination, and is essential for travel promotion.

The destination environment in the perception of tourists is very attractive. Tourism destination management must consider several factors to match this level, by providing a place with a satisfactory level of cleanliness, affordable costs, good quality technological infrastructure, as well as a level of safety and security. High quality of service does not necessarily make tourists satisfied, but other important factors influence it such as the belief of tourists that religious tourism is a form of worship that can increase health immunity, besides that religious tourism is a form of love for religious leaders from Madura, which has spread Islam in Indonesia and especially on the island of Madura.
The results in the current study highlight that a high level of service quality, when combined with the destination image produced by local communities, can certainly increase tourist satisfaction, so that tourists can convey positive information about the quality of servants and the destination image from religious tourism destinations on Madura Island. The results showed that customer satisfaction is the bridge between service quality and destination image to tourist revisit intention, meanwhile service quality and destination image is the most important predictor of tourist revisit intention.

Regardless of the theoretical and practical implications mentioned above, this study still has several limitations. First, existing studies focus primarily on data for a specific period. In further research, data from different periods must be obtained, and studies with different periods must be combined. Second, each region or country has its own cultural, geographic, and economic background, so a more empirical case analysis is needed and complements the data with more interviews, and this will undoubtedly increase the effectiveness of the research results. Thus, future research can explore the relevance and relative importance of various factors, including reliability, safety, and frequency, as well as provide accurate and accessible information in multicultural and multi-regional contexts.

\section{REFERENCES}

Abubakar, B and Mavondo, F. (2014) Tourismn Destination: Antecendents to Customer Satisfaction and Positive Word ofMouth, J. Hosp. Mark. Manag., 23(8), 833-864.

Akbar, M.M and Parvez. (2009). Impact of Service Quality, Trust, and Customer Satisfaction Loyalty, ABAC Journal, 29(1), 24-38.

Andreassen, T.W. dan Lindestad, B. (1997). Customer loyalty and complex services - The impact of corporate image and loyalty for customer with varying degrees of service expertise. International Journal of Service Industry Management. Vol. 9/1, MCB University Press.

Ball, A. D., Coelho, P. S., \& Machás, A. (2004). The role of communication and trust in explaining customer loyalty: An extension to the ECSI model. European Journal of Marketing, 38(9/10), 1272-1293.

Baker, D.A. dan Crompton, J.L. (2000). Quality, satisfaction and behavioral intentions. Annals of Tourism Research. 27(3), 785804.

Bigné, J., Sánchez, M., \& Sánchez, J. (2001). Tourism image, evaluation variables and after purchase behaviour: Interrelationship. Tourism Management, 22(6), 607-616.

Bolton, R. N., \& Drew, J. H. (1991). A multistage model of customers' assessments of service quality and value. Journal of Consumer Research, 17(4), 375-384.

Bollen, K. A. (1989). Structural equations with latent variables (1st ed., pp. 80-148). Wiley.

Canming, C., \& Jianjun, C. (2011). An empirical analysis of the relationship among the service quality, customer satisfaction, and loyalty of high-speed railway based on structural equation model. Canadian Social Science, 7, 67-73.

Caruana, A. (2002). Service loyalty: The effects of service quality and the mediating role of customer satisfaction. European Journal of Marketing, 36(7/8), 811-828.

Chen, C.F. and Chen, F.S. (2010), "Experience quality, perceived value, satisfaction and behavioral intentions for heritage tourists", Tourism Management, 31(1), 29-35

Chou, J. S., \& Kim, C. (2009). A structural equation analysis of the QSL relationship with passenger riding experience on high-speed rail: An empirical study of Taiwan and Korea. Expert Systems with Applications, 36, 6945-6955. 
Cronin, J.J dan Taylor, S.A. (1992). "Measuring Service Quality: A Reexaminataion and Extension", Journal of Marketing, Juny (56): 55-68.

Eboli, L., \& Mazzulla, G. (2011). A methodology for evaluating transit service quality based on subjective and objective measures from the passenger's point of view. Transport Policy, 18, 172-181.

Eboli, L., \& Mazzulla, G. (2012). Structural equation modeling for analyzing passengers' perceptions about railway services. Procedia-Social and Behavioral Sciences, 54, 96-106.

Fornell, C., \& Larcker, D. F. (1981). Evaluating structural equation models with unobservable variables and measurement error. Journal of Marketing Research, 18, 39-50.

Fornell, C. (1992). A national customer satisfaction barometer: The Swedish experience. Journal of Marketing, 56(1), 6-21.

Fullerton, G., \& Taylor, S. (2002). Mediating, interactive, and non-linear effects in service quality and satisfaction with services research. Canadian Journal of Administrative Sciences, 19(2), 124- 136.

González, M.E.A., Comesana, L.R. \& Brea, J.A.F. (2007). Assessing Tourist Behavioral Intentions through Perceived Service Quality and Customer Satisfaction. Journal of Business Research, 60: 153160.

Hassan, M. N., Hawas, Y. E., \& Ahmed, K. (2013). A multi-dimensional framework for evaluating the transit service performance. Transportation Research Part A: Policy and Practice, 50, 47-61.

Hossain, Mohammed, and Shirley, Leo (2008). Customer perception on service quality in retail banking in the Middle East: the case of Qatar. International Journal of Islamic and Middle Eastern Finance and Management, 2(4): 338-350.

Jen, W., Tu, R., \& Lu, T. (2011). Managing passenger behavioral intention: An integrated framework for service quality, satisfaction, perceived value, and switching barriers. Transportation, 38, 321342 .

Kim, Y. H., Kim, M., \& Goh, B. K. (2011). An examination of food tourist's behavior: Using the modified theory of reasoned action. $\begin{array}{llr}\text { Tourism Management, } & 32(5), & 1159-1165 .\end{array}$ doi:10.1016/j.tourman.2010.10.006

Kotler, Philip. (2002). Manajemen pemasaran. Jilid kedua. (10th ed). Jakarta: Prenhallindo.

Kotler, P. and G Armstrong. (2004). Principle of Marketing: 10thnEdition. New Jersey: Prentice-Hall.

Kristianto, Paulus Lilik. (2011). Psikologi Pemasaran. Yogyakarta: CAPS.

Lawson, F., and M. Bond-Bovy. (1977). Tourism and Recreational Development. London: Architectural Press.

Lee, H., Lee, Y., \& Yoo, D. (2000). The determinants of perceived service quality and its relationship with satisfaction. Journal of Services Marketing, 14(3), 217-231.

Marinkovic, V., Senic, V., Ivkov, D., Dimitrovski, D., \& Bjelic, M. (2014). The antecedents of satisfaction and revisit intentions for full-service restaurants. Marketing Intelligence \& Planning, 32(3), 311-327. doi:10.1108/MIP-01-2013-0017

Mukhles Al-Ababneh (2013). Service Quality and its impact on Tourist Satisfaction. Interdisciplinary Journal of Contemporary Research in Business, 4(12); 164-177.

Nathanail, E. (2008). Measuring the quality of service for passengers on the Hellenic Railways. Transportation Research Part A: Policy and Practice, 42, 48-66.

Oliver, (1997), Satisfaction: A behavioral perspective on the consumer. New York, NY: McGraw-Hill.

Oliver, R. L. (1980). A cognitive model of the antecedents and consequences of satisfaction decisions. Journal of Marketing Research, 17, 460-469.

Pan, H., Shen, Q., \& Xue, S. (2010). Intermodal transfer between bicycles and rail transit in Shanghai, China. Transportation Research Record, 2144, 181-188.

Parasuraman, A., Zeithaml, V., \& Berry, L. (1988). SERVQUAL: A multiple-item scale for measuring consumer perceptions of service quality. Journal of Retailing, 64, 12-40.

Pitana, I G., Gayatri, PG. (2005). Sosiologi Pariwisata. Andi: Yogyakarta

Raheem, A., Mohammed, J., Salehuddin, M., Suhaimi, \& Mohd. Z. (2014). The Causal Relationships between Destination Image, Tourist Satisfaction and Revisit Intention: A Case of the United Arab Emirates.

Rossiter, J. R. (2002). The C-OAR-SE procedure for scale development in marketing. International Journal of Research in Marketing, 19(4), 305-335.

Shen, W., Xiao, W., \& Wang, X. (2016). Passenger satisfaction evaluation model for Urban rail transit: A structural equation modeling based on partial least squares. Transport Policy, 46, 2031.

Shonk, D.J. and Chelladurai, P. (2008) Service Quality, Satisfaction, and Intent to Return in Event Sport Tourism. Journal of Sport Management, 22, 587-602.

Tjiptono, F. (2012). Service management: mewujudkan layanan prima (create excellent service). Yogyakarta: Andi Offset.

Wantara, P. (2015). The Relationships among Service Quality, Customer Satisfaction, and Customer Loyalty in Library Services. International Journal of Economic and Financial Issues, 5(Special Issue), 264-269.

Wu, H.C., Li, M.Y. and Li, T. (2014). A study of experiental quality, experiental value, experiental satisfaction, theme park image and Revisit intention. Journal of Hospitality and Tourism Research, Vol. 42 No. 1, pp. 26-73.

Yang, L. J. S., \& Wu, H. C. J. (2013, November 16). An empirical study of synthesizing the effects of service quality, emotions, corporate image and customer satisfaction on revisit intentions in the hot spring industry. Paper presented at International Symposium of Quality Management: New Eco-era's Business Quality, Kaohsiung, Taiwan.

Yang, L. J. (2014). A study of revisit intentions, customer satisfaction, corporate image, emotions, and service quality in the hot spring industry: The case of Anning City in Yunnan Province (Unpublished master's thesis). Macau University of Science and Technology, Macau.

Yilmaz, V., \& Ari, E. (2017). The effects of service quality, image, and customer satisfaction on customer complaints and loyalty in highspeed rail service in Turkey: A proposal of the structural equation model. Transportmetrica A: Transport Science, 13, 67-90.

Zeithaml, V.A. \& Bitner, M.J. (2003). Service Marketing: Integrated Customer Focus Accross the Firm, Burr Ridge, IL: Irwin-McGraHill.

Zeithaml, V., Bitner, M.J.\& Gremler, D. (2009). Service Marketing: Integrated Customer Focus Across the Firm, New York: McGrawHill. 